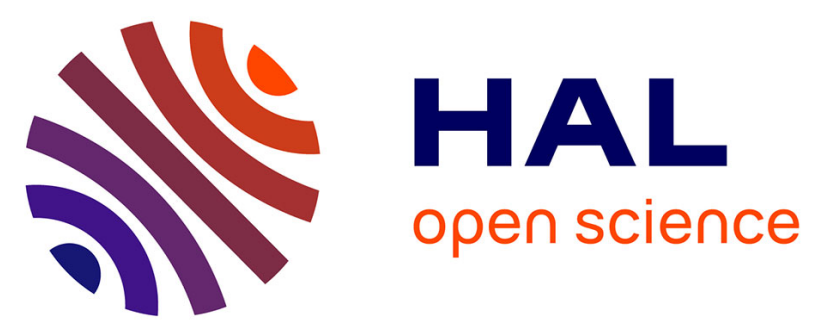

\title{
Early screening of new accumulating versus non-accumulating tree species for the phytomanagement of marginal lands
}

\author{
Lisa Ciadamidaro, J. Parelle, F. Tatin-Froux, C. Moyen, A. Durand, C. \\ Zappelini, N. Morin-Crini, D. Soupe, D. Blaudez, M. Chalot
}

\section{To cite this version:}

Lisa Ciadamidaro, J. Parelle, F. Tatin-Froux, C. Moyen, A. Durand, et al.. Early screening of new accumulating versus non-accumulating tree species for the phytomanagement of marginal lands. Ecological Engineering, 2019, 130, pp.147-156. 10.1016/j.ecoleng.2019.02.010 - hal-02089637

\section{HAL Id: hal-02089637 https://hal.science/hal-02089637}

Submitted on 18 Apr 2019

HAL is a multi-disciplinary open access archive for the deposit and dissemination of scientific research documents, whether they are published or not. The documents may come from teaching and research institutions in France or abroad, or from public or private research centers.
L'archive ouverte pluridisciplinaire HAL, est destinée au dépôt et à la diffusion de documents scientifiques de niveau recherche, publiés ou non, émanant des établissements d'enseignement et de recherche français ou étrangers, des laboratoires publics ou privés. 
1 Early screening of new accumulating versus non-accumulating tree species

2 for the phytomanagement of marginal lands

3

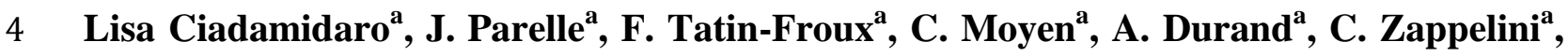

5 N. Morin-Crini ${ }^{\mathrm{a}}$, D. Soupe ${ }^{\mathrm{b}}$, D. Blaudez ${ }^{\mathrm{c}}$ and M. Chalot ${ }^{\mathrm{a}, \mathrm{d}}$

6

7 ânniversité de Bourgogne Franche-Comté, UMR CNRS 6249 Laboratoire Chrono8 environnement, Pôle Universitaire du Pays de Montbéliard, 4 place Tharradin, BP 71427, F9 25211, Montbéliard, France.

${ }^{b}$ Pépinières Daniel SOUPE S.A.S., Les Lazares - Route de Thoissey, 01400 Châtillon sur 11 Chalaronne, France.

${ }^{c}$ Université de Lorraine, CNRS, LIEC, F-54000 Nancy, France.

${ }^{\mathrm{d}}$ Université de Lorraine, F-54000 Nancy, France. 
The use of fast-growing trees producing a high quantity of biomass can bring significant practical and economic benefits to the reclamation of marginal lands. The present study aims to identify new shrub/tree species to offer a wider range of shrubs/trees useful for phytomanagement practices. We implemented three experimental sites in France of 1 ha each (Thann, Carrières-sous-Poissy and Leforest) contaminated by different potentially toxic elements (PTE) with a total of 38 different tree species. After two years of growth, the element concentrations in stem and leaf biomasses, tree survival rate and growth of plants were assessed. Although the three sites had elevated concentrations of total PTE and nutrients in their soil, the element contents in the trees strongly differed depending on the species. Alnus subcordata, Platanus orientalis, Ulmus pumila, Ostrya carpinifolia and the Acer species appeared to be well adapted to the drastic conditions of the sites and presented the lowest PTE concentrations in their aboveground biomass. Conversely, the Salix, Populus, Betula and Quercus species, especially Salix aquatica grandis, exhibited the highest accumulations of $\mathrm{Cd}, \mathrm{Zn}$ and/or $\mathrm{Mn}$ at the three sites. Inoculation with the endomycorrhizal fungus Rhizophagus irregularis did not have a significant impact on the growth of the tree production of TE-enriched biomass that could be better exploited in the eco-catalysis process.

Key words: Non-accumulating tree species, trace elements, phytomanagement, Salix aquatica grandis 


\section{Introduction}

Pollution has been identified by the European Commission as a major threat to soils. In EU countries, the number of potentially contaminated sites adds up to nearly 3 million (Europe's environment - The fourth assessment). More than 250,000 polluted sites in the member states require urgent clean up. Due to several anthropogenic activities, such as mining, industries and the production of agricultural wastewater, the spread of PTE in the environment has become a major problem (Khan et al., 2010; Sheoran et al., 2010). Therefore, the remediation of polluted soils is crucial to ensure that soil remains a key natural resource for human society and to promote sustainable environment and economic development. As such, pollution treatment represents an economic need, which often remains unanswered by conventional civil engineering methods due to their inappropriateness, environmental impact and costs (notably for large sites). Currently, several phytotechnologies can be considered and applied to PTE polluted soils: (1) phytostabilization, which uses perennials able to sorb and immobilize potentially toxic PTE in the root zone, avoiding their transfer towards groundwater and aerial parts, preventing their bioaccumulation in the food chain, as well as their dispersion by natural agents (wind erosion, water); and (2) phytoextraction, which is based on root-to-shoot transfer and the storage of potentially toxic PTE in harvestable tree parts (Pilon-Smith, 2005). These eco-innovative phytotechnologies can remediate soil layers in contact with the roots and at the same time provide tree biomass (Robinson et al., 2009), which can be used to reach the targets for the use of renewable energy sources (Mench et al., 2009, Ciadamidaro et al., 2017).

The suitability of a certain plant for PTE remediation is determined by various plant properties, such as: (i) heavy metal tolerance; (ii) size, growth rate and rooting depth; (iii) heavy metal accumulation in above-ground plant parts; and (iv) climatic adaptation and pest resistance (Kirkham, 2006; Pulford and Watson, 2003). Over the years, several studies have 
been carried out to optimize the method and to find the most suitable plants. Poplars and willows have been extensively tested for the phytoremediation of land polluted by PTE (Dickinson, 2006; French et al., 2006; Meers et al., 2007; Ciadamidaro et al., 2014). Their potential resides in large biomass production, extensive root systems, considerable tolerance to PTEs, and high accumulation of PTE in the biomass (Pulford and Watson, 2003). Other studies (Mertens et al., 2007; Evangelou et al., 2012) have tested different trees, such as birch (Betula pendula), oak (Quercus robur), ash (Fraxinus excelsior) and maple (Acer pseudoplatanus) and demonstrated different behaviors and adaptation characteristics to PTE contamination. These differences have had impacts on the final outcome of phytomanagement strategies, and a careful selection of appropriate tree species/clones seems to be a prerequisite for any field-based phytoremediation attempts (Pulford and Watson, 2003).

During the last two decades, we have witnessed the emergence of using different tree species in combination with microbial biotechnologies (Mench et al., 2010). It is now widely recognized that microorganisms are of utmost importance for the efficacious establishment of phytomanagement strategies (Moreira et al., 2016). Indeed, it is now proved that mycorrhizal fungus associations enhance plant growth at field levels (Ciadamidaro et al., 2017) and vitality on TE-disturbed habitats and reduce metal toxicity, affecting plant metal uptake and further accumulation in plant tissues (Phanthavongsa et al., 2017). Moreover, mycorrhizal fungi enhances plant growth and their resistance to adverse conditions including toxicity produced by TEs, affecting the phytoavailability of TEs in soil and the uptake of metals by plants from soil and translocation from root to shoot (Yilmaz and Parlak, 2011, Meier et al., 2012). Most importantly, the selection of adequate trees and microbes is a key feature in a phytomanagement approach (Ciadamidaro et al., 2017). However, current knowledge about the performance of trees and their associated microbes in phytomanagement strategies is particularly limited to a few genera, such as Populus and Salix (Dominguez et al., 2008; 
Ciadamidaro et al., 2014, Phanthavongsa et al., 2017).

We hypothesized that testing a large number of woody species on various marginal lands would increase the panel of trees relevant for phytomanagement. The purpose of the present study was to identify a panel of woody species with phytoremediating capacities, either within a phytostabilization strategy (high productivity, low PTE accumulation), or within a phytoextraction strategy (high productivity, high PTE accumulation), which would allow greater efficiency and ensure the biodiversity needed to restore the ecosystem. We chose to work on a short time scale to be able to rapidly select species useful for phytomanagement. To better address the question of the replicability of our data, we implemented three different sites with different contamination histories. We also aimed to test the impact of endomycorrhizal inoculation on the PTE uptake by various tree species.

\section{Materials and methods}

\subsection{Site description and soil preparation before plantation}

The experiment was carried out at three different sites, i.e., Thann, Carrières-sousPoissy and Leforest, where phytomanagement has been identified as a relevant strategy to remediate soil pollution.

The experimental site of Thann is located in the valley of the Thur in Alsace-France $\left(47^{\circ} 47^{\prime} 48.4^{\prime \prime} \mathrm{N} 7^{\circ} 08^{\prime} 20.8^{\prime \prime} \mathrm{E}\right)$ near the border with Germany and Switzerland, on a 15 hachemistry-based industrial complex. The Thann plant owned by the Cristal company is one of the most important sites for $\mathrm{TiO}_{2}$ production in Europe and is the second-largest production facility in the world (Assad et al., 2017). The Ti extraction process generates tailings made of red gypsum from the neutralization and precipitation of effluents containing sulfuric acid, which is used to dissolve the PTE contained in the ore. Red gypsum, a solid residue enriched with $\mathrm{Fe}, \mathrm{S}$ and $\mathrm{Mn}$, is stored on the Ochsenfeld landfill (Alsace, France), located on an 80-ha landfill $3 \mathrm{~km}$ away from the industrial complex. The landfill site was prepared before 
plantation by adding a 30-cm layer of soil obtained from a local source and incorporated into the red gypsum layer by plowing to a depth of $50 \mathrm{~cm}$. Previous assays have indeed demonstrated the need for reconstructing a soil layer to allow for tree growth prior to 140 plowed to a depth of $30 \mathrm{~cm}$. plantation. Direct implementation on the red gypsum substrate would result in poor growth and high mortality at this site.

The experimental site at Carrières-sous-Poissy (4857'39.7"N 202'09.6"E) was watered with raw wastewater of the Paris conurbation from 1899 to 2002 , hence becoming highly enriched in nutrients and organic matter $(\mathrm{OM})$ and accelerating the production of market vegetables until the late 1990's (Lamy et al., 2006). However, PTE accumulation in the soil led to multi-pollution characterized by $\mathrm{Pb}, \mathrm{Zn}$ and $\mathrm{Cd}$ concentrations 10 times higher than those in a non-irrigated reference soil. Before plantation, the soil was plowed to a depth of $30 \mathrm{~cm}$.

The experimental site at Leforest is located close to Noyelles-Godault, in Northern France $\left(50^{\circ} 25^{\prime} 40.5^{\prime \prime} \mathrm{N} 3^{\circ} 02^{\prime} 40.5^{\prime \prime} \mathrm{E}\right)$, in the proximity of the Metaleurop plant, which is one of the biggest $\mathrm{Zn}$ and $\mathrm{Pb}$ production units in Europe (Douay et al., 2009). It was built in 1894 and produced approximately 170,000 tons of $\mathrm{Pb}$ and 105,000 tons of $\mathrm{Zn}$ per year until it was closed in 2003. This plant produced a significant quantity of dust, and its fallout contaminated the adjacent area to a distance of several $\mathrm{km}$, with high amounts of $\mathrm{Cd}, \mathrm{Zn}$ and $\mathrm{Pb}$. Studies have been undertaken to investigate the nature of the contamination (Sterckeman et al., 1996) and the transfer of contaminants to local vegetation (Azimi et al., 2003; Migeon et al., 2009; Pourrut et al., 2011) and macrofauna (Pauget et al., 2013). Before plantation, the soil was

\subsection{Experimental design}

The three experimental sites were established in November 2013 (Carrières-sousPoissy) and April 2014 (Thann and Leforest). Each site was divided into 8 different plots, in 
144 half of them the rooted trees were inoculated (4 inoculated plots $x$ tree species $x$ site) with a 145 commercial mycorrhizal inoculum and the other half was left non-inoculated (4 control plots $146 x$ tree species $x$ site). The fungal inoculum consisting of the AM Rhizophagus irregulare DAOM 197198 strain was provided by the Agronutrition company (Toulouse, France). The inoculation was performed at the nursery prior to plantation by soaking the roots into a mixture of propagules / peat (200000 propagules / $5 \mathrm{~L}$ of peat).

The experimental designs slightly differed from site to site as detailed hereafter. At the Thann site $\left(8250 \mathrm{~m}^{2}\right)$, each plot consisted of 18 different tree species (594 trees per plot, i.e., a total of 4752 trees) and each tree species was represented by 264 individuals distributed equally in each of the 8 plots (33 individuals per tree species per plot). The trees were planted in lines with a spacing of $0.60 \mathrm{~cm}$, resulting in a final density of 5760 trees/ha. At the Carrières-sous-Poissy $\left(9840 \mathrm{~m}^{2}\right)$ and Leforest $\left(8706 \mathrm{~m}^{2}\right)$ sites, each plot consisted of 16 different tree species (496 trees per plot, i.e., a total of 3968 trees), and each tree species was represented by 248 individuals distributed equally in each of the 8 plots (31 individuals per tree species per plot). The trees were planted in lines with a spacing of $0.70 \mathrm{~cm}$, resulting in final densities of 4033 and 4558 trees/ha for Carrières-sous-Poissy and Leforest, respectively. The criteria for the selection of tree species at each site were as follows: recognized environmental adaptations to local soil conditions, endogenous characteristics (spontaneous presence at the site), level of production at the nursery, and, in some cases, the lack of data in the phytomanagement literature. The three sites contained three tree species in common (Ostrya carpinifolia, Pterocarya stenoptera and Salix aquatica grandis). The Carrières-sousPoissy and Leforest sites had 4 additional tree species in common (Populus oxford, Quercus petraea, Quercus cerris and Quercus pedunculata). The Thann and Leforest sites had 2 additional tree species in common (Platanus orientalis and Salix alba). A detailed list of the tree species implemented at each site is reported in Table 1. 


\subsection{Soil and tree analyses}

\subsubsection{Soil physico-chemical characterization}

At site implementation, 10 top-soil $(0-20 \mathrm{~cm})$ samples were gathered from each plot with a hand auger after site preparation and mixed together to create composite samples. The 24 soil composite samples (3 sites $\times 1$ composite samples) were analyzed for physicochemical characterization. The soil samples were dried at $40{ }^{\circ} \mathrm{C}$ in a forced air oven to a constant weight and ground with a grinder (agate mortar, Retsch RM100). The samples were sent to a certified laboratory (SADEF, France) for the following analyses: particle size distribution, exchangeable $\mathrm{Ca}(\mathrm{CaO}), \mathrm{Mg}(\mathrm{MgO}), \mathrm{K}\left(\mathrm{K}_{2} \mathrm{O}\right)$ and $\mathrm{Na}\left(\mathrm{Na}_{2} \mathrm{O}\right)$, cation exchange capacity (CEC) (NF X 31-130), organic matter (OM) (NF ISO 14235), total $\mathrm{CaCO}_{3}$ (NF ISO 10693), total nitrogen $\left(\mathrm{N}_{\mathrm{t}}\right)$ (NF ISO 13878), total phosphorus (Joret-Hebert method) (NF X 31-161) and soluble boron (B) (NF X 31-122).

\subsubsection{Soil and plant trace element analyses}

The total element concentrations ( $\mathrm{Al}, \mathrm{Cd}, \mathrm{Fe}, \mathrm{Mn}, \mathrm{Pb}, \mathrm{S}, \mathrm{Zn}$ ) in the soil at the start time were determined using inductively coupled plasma atomic emission spectrometry (ICPAES, Thermo Fischer Scientific, Inc., Pittsburgh, USA) following the acid digestion of 500 mg of sample (DigiPREP system, SCP Sciences, Courtaboeuf, France) using a mix of $2 \mathrm{~mL}$ of $67 \%$ nitric acid, $6 \mathrm{~mL}$ of $34 \%$ hydrochloric acid and $2 \mathrm{~mL}$ of $48 \%$ hydrofluoric acid. The available element concentrations in the soil were assessed using a $0.01 \mathrm{M} \mathrm{CaCl}_{2}$-extraction with a sample extraction ratio of 1:10 (Houba et al., 1996) via ICP-AES. The total and available elemental concentrations in the soils are reported in Table 3.

At each sampling site, leaves and stems from 6 trees per plant species per plot were sampled in autumn 2015, for a total of 2400 analyses. Leaf and stem samples were washed with distilled water, dried at $70^{\circ} \mathrm{C}$ for at least $48 \mathrm{~h}$, and ground using a stainless-steel mill. The studied elements (Al, Cd, Fe, Mn, Pb, S and $\mathrm{Zn}$ ) were determined by ICP-AES following 
194 the acid digestion with concentrated $\mathrm{HNO}_{3}$ (DigiPREP system). All samples were run 195 together with certified reference materials, including oriental basma tobacco leaves (INCT196 OBTL-5, LGC Promochem, Molsheim, France) and a loamy clay soil (CRM052, LGC 197 Promochem, Molsheim, France). The percentage of recovery of the studied elements ranged 198 between 77 and $110 \%$.

\subsubsection{Tree survival rate and growth estimation}

The survival rates of plants were estimated in 2015. To avoid destructive sampling at this stage, after two years of growth, tree development was estimated by measuring the tree heights (Fig. 1) of all trees at the three sites in October 2015 and compared to the nursery 203 standard. The nursery trees were grown in soil for the same length of time, without any fertilizers nor irrigation. However, they did not experience the transplantation event. The height of each tree was estimated in the following ranges expressed in cm: 40/60; 60/80; $80 / 100 ; 100 / 120 ; 120 / 150 ; 150 / 175 ; 175 / 200 ; 200 / 250$. The initial height of the planted trees was $40 / 60$. Once the growth report was completed, an average value was assigned to each tree.

\subsection{Statistical analyses}

Statistical analyses were carried out using R 3.2.0 software (R Development Core Team, 2015) for Windows, and the results are expressed as mean values with standard deviations. All tests were considered significant when $p<0.05$. Normality of variable or residual values were tested with a Shapiro-Wilk test and homoscedasticity with a Bartlett test.

The mean comparison between treatments (Control and Inoculated) for the results of nutrients and trace elements in soil was performed using post hoc tests following a one-factor 216 analysis of variance (ANOVA) considering the sites separately and each site as the independent variable. To test the effects of the inoculation and tree species on PTE uptake in 
significance $(\mathrm{P} \leq 0.05)$ of each studied variable. Significant differences in soil variables between treatments were established by the Tukey test at $\mathrm{p}<0.05$. PCA analyses were performed using the FactoMinR package: data below the limit of quantification were considered to be null for the calculation of the principal components, and ellipses were drawn at the $95 \%$ confidence interval of the barycenter of each species.

\section{Results}

\subsection{Soil characteristics}

The main characteristics of the three studied soils are reported in Table 2. The average $\mathrm{pH}$ values of the three sites were close to neutrality or slightly acidic $(7.4,7.2$ and 6.5 for Thann, Carrières-sous-Poissy and Leforest, respectively). The soil texture was sandy-silt, sandy and silty-loam for Thann, Carrières-sous-Poissy and Leforest, respectively. The organic status reported in Table 2 demonstrated that Carrières-sous-Poissy presented much higher values of $\mathrm{C}$ and $\mathrm{N}\left(39.6 \mathrm{~g} / \mathrm{kg}\right.$ of $\mathrm{C}_{\mathrm{org}}, 68.5 \mathrm{~g} / \mathrm{kg}$ of $\mathrm{OM}$ and 3.78 of $\left.\mathrm{N}_{\text {tot }}\right)$ in comparison with the other two sites, especially the Thann site. In general, for the exchangeable oligos, higher values were observed for Carrières-sous-Poissy and Leforest, except for $\mathrm{Na}_{2} \mathrm{O}_{\mathrm{ex}}$ at Carrièressous-Poissy.

Although a set of elements in the soil was analyzed, only the most abundant and the major contaminants are shown for this study (Table 3). The results showed high total concentrations in soil for all of the elements reported in Table 3, except for Cd at Thann. According to these values, Thann presented much higher contents of $\mathrm{Fe}, \mathrm{Mn}$ and $\mathrm{S}$, whereas Carrières-sous-Poissy and Leforest exhibited higher values of $\mathrm{Cd}, \mathrm{Pb}$ and $\mathrm{Zn}$ and were similar to those obtained in previous studies of metal-contaminated sites in France (Assad et al., 2017, Foulon et al., 2016a, b; Douay et al., 2013; Lamy et al., 2006; Pourrut et al., 2011). The $\mathrm{CaCl}_{2}$ extractable fractions also differed between sites and followed the same trends of the total concentrations, except for $\mathrm{Mn}$ at Thann. Indeed, the $\mathrm{Mn} \mathrm{CaCl}_{2}$ extractable fractions at 
Leforest accounted for approximately $5 \%$ of the total Mn, whereas at Thann it accounted for

245 less than $0.03 \%$. Pb was not detected in the $\mathrm{CaCl}_{2}$ extractable fractions for any of the sites.

246 Despite its elevated total concentrations of most elements, the Thann soil was less appropriate 247 for plant growth, as the availability of its nutrients was rather low.

\subsection{Tree development at the three experimental sites}

For each species and each site, the survival rates are given for the 8 plots (Table S4).

The data were compared with the average rate of survival seen in nurseries (an average of 90\% after 2 years, under favorable soil and crop conditions). Due to the high mortality after the first year for unknown reasons, the Betula species needed to be replanted in January 2016. After 2 years of growth, the average survival rates at the Thann, Leforest and Carrières-sousPoissy sites were $73 \%, 77 \%$, and $85 \%$, respectively, which seems acceptable considering the soil constraints (high PTE loads) of the sites and the drastic weather conditions during summer 2015, which were marked by a strong drought.

During the year 2015, non-destructive plant measurements were undertaken, as 258 described in the "materials and methods" section. The levels of tree growth at the Thann and 259 Leforest sites were $42 \%$ and $20 \%$ lower than the nursery standards, respectively (Fig. 1). This 260 reduced growth could be attributed to different factors, such as: i) site-specific soil-climatic conditions; ii) less follow-up and care than in nurseries; iii) an exceptional level of drought in 262 the summer of 2015; iv) animal (rabbits and wild boar) grazing. The nursery data are provided 263 in our manuscript as indicators of the optimal nursery performance for commercial purposes, 264 but they cannot be considered as experimental controls. As is often the case in field 265 experimental design, it was not possible to have field controls, as the studied sites lacked non266 contaminated areas. Climatic conditions during the experimental period are reported in Table 267 S1. The 2013 to 2015 data were in the range of the overall weather data at the three sites and 
comparable. The 2015 summer (June or July) was however remarkably drier and warmer than the previous years, at the three sites.

Contrasting differences were reported for the following tree species at the Thann site: i) Z. serrata, with a growth rate $34 \%$ higher than that of the standards; ii) the Salix, Platanus, Ulmus and Ostrya species slightly grew less than the nursery standards; and iii) and a clear difference observed for the other species, for which tree growth was reduced by $61 \%$ on average and by up to $75 \%$ for the three Quercus species (Fig. 1). At the Carrières-sousPoissy site, tree growth was overall only $14 \%$ lower than that of the nursery standards (Fig. 1). Most of the tree species performed quite well, with the Acer, Eleagnus, Fraxinus, Ostrya and Syringa species exhibiting heights equaling or exceeding the nursery standards. The Paulownia species showed the lowest growth rate. At the Leforest site, the Alnus, Platanus, Populus and Salix (3 species) showed worthy performances compared to the nursery standards. The growth of the two Quercus species was significantly lower than that of the standards (Fig. 1). Moreover, P. stenoptera as well as S. aquatica grandis and S. caprea appeared to be particularly impacted by the site conditions.

\subsection{Elements in trees (leaves and stems)}

The element concentrations of leaves and stems are detailed in Tables S2 and S3. For all the studied elements in leaves, a MANOVA was performed (Table S5) in order to highlight the effects of treatments $(I)$, tree species $(S)$ and interaction $(I x S)$ between these two factors. The species $(S)$ is the dominant factor affecting PTE accumulation in leaves at all sites. In general, inoculation $(I)$ had no significant effect on PTE accumulation at the 3 sites (Table S5). Only at the Thann site, an interaction effect between treatment and species ( $I x S)$ slightly influenced the $\mathrm{Al}, \mathrm{Fe}$ and $\mathrm{Pb}$ concentrations in leaves and that of $\mathrm{Al}$ at the Leforest site (Table S5). Therefore, according to these MANOVA results, data from the control and inoculated trees were pooled in all the following analyses. 

multivariate analysis (PCA). Based on the PCA, the Salix, Populus and Betula species for the three sites and, additionally, the 3 Quercus species for Thann site were closely correlated with the major PTE contents $(\mathrm{Cd}, \mathrm{Pb}, \mathrm{Zn}$ and $\mathrm{Mn})$. The strongest correlations were observed for $S$. aquatica grandis, one of the three common species in all the sites, for $\mathrm{Cd}, \mathrm{Zn}, \mathrm{Ni}$ and $\mathrm{Co}$ (Fig. 298 2, a-f), and for B. verrucosa with Mn at the Thann site (Fig. 2, a and b). In more detail, the 299 Salix, Populus and Betula species showed the highest accumulation capacities for $\mathrm{Cd}$ and $\mathrm{Zn}$ 300 in their leaves, with especially very high values for the Salicaceous species growing at 301 Leforest (Table S2). In particular, S. aquatica grandis demonstrated the highest capacity to 302 accumulate $\mathrm{Cd}(>100 \mu \mathrm{g} / \mathrm{g} \mathrm{DM})$ and $\mathrm{Zn}(>2500 \mu \mathrm{g} / \mathrm{g} \mathrm{DM})$. . P. stenoptera at the Leforest site 303 was the only species never tested before in phytomanagement, which demonstrated an 304 accumulation capacity for $\mathrm{Zn}$ in leaves but at lower levels than those observed for the 305 Salicaceous species. Concerning Mn, only species grown at the Thann site accumulated 306 higher Mn contents compared with the range considered to be "physiological" in tree leaves. 307 Species of the genera Salix, Betula and Quercus showed high Mn uptake capacities. At the 308 same time, they were also able to accumulate Fe and S (the other principal elements at the 309 Thann site) in leaves above the range considered physiological in trees, reaching values $\approx$ 310 $400 \mu \mathrm{g} / \mathrm{g} \mathrm{Mn}$ for Q. rysophylla and B. papyrifera and >300 $\mu \mathrm{g} / \mathrm{g}$ Mn for S. aquatica grandis

311 (Table S2). For the three sites, all the other elements analyzed were in the background range 312 for PTE in plants (Table S2) according to Kabata-Pendias and Pendias (1992) and for Fe 313 according to Bowen (1979).

314 In contrast, the PTE contents and PCA analysis revealed that P. orientalis, U. pumila, 315 O. carpinifolia and the 3 studied Acer species showed poor or no correlation at all with any of 316 the elements measured in the leaves at the three sites. In this work, species of the genera Acer, 317 Alnus, Eleagnus, Fraxinus, Hippophae, Quercus, Ostrya, and Paulownia (which have only 
seldom been tested in phytomanagement studies), did not show any accumulative trait for the elements measured.

We further analyzed the elemental concentrations in stems (Table S3). However, this analysis was restricted to those species that accumulated PTE in their leaves, since the stem element contents are usually lower than the leaf contents. For a general interpretation of the PTE concentrations in stems depending on the selected tree species, the data are presented as sunray plots, and the values of each tree species were transformed to their corresponding logarithms in order to fit them into the graphs (Fig. 3). In general, the PTE concentrations in stems were 5-10 times lower than the PTE concentrations in leaves (Tables S2 and S3). Nevertheless, the results confirmed the trends observed in leaves for all tree species, i.e., the higher accumulation of $\mathrm{Cd}$ and $\mathrm{Zn}$ at the Leforest site for $\mathrm{S}$. aquatica grandis and that of $\mathrm{Mn}$ at the Thann site for $Q$. cerris, Q. pedunculata and B. papyrifera.

\section{Discussion}

Overall, in the present study, we tested the growth performance and element accumulation of 38 tree species at three different marginal lands. This set of data allowed us to identify two groups of trees that could be useful for phytomanagement strategies.

The first group includes species that grew rather well and did not accumulate PTEs. Our results based on growth data (Fig. 1 and Table S4) and PCA analysis (Fig. 2) showed that O. carpinifolia performed very well on the three sites compared to the nursery standard and accumulated PTE in the leaf tissues within normal physiological levels (Table S2) (KabataPendias and Pendias, 2001; Bowen, 1979). To our knowledge, this tree species has never before been tested in a phytomanagement context. Similarly, P. orientalis showed good growth capabilities at two of the three sites (Thann and Leforest). In addition, 2 Fraxinus and 2 Syringa species, the Acer, Alnus, Carpinus, Hippophae, Ulmus and Zelkova species, performed rather well on at least one experimental site, showing no accumulation of PTE. The 
satisfying potential growth of these species makes them good candidates for the restoration of marginal lands at no risk, since the produced biomass will be clean enough to further limit the recycling of contaminants through leaf fall. There is almost no data on the phytomanagement capacity of P. orientalis, U. pumila, O. carpinifolia, A. saccharinum and Z. serrata trees. Similar results were only found by Mertens et al. (2007), in which A. pseudoplatanus was able to reduce the mobilization of PTE in a contaminated site. According to our findings, these tree species could be considered relevant for phytomanagement strategies due to their capacity of reducing PTE uptake, exploiting tree transpiration and root growth in order to decrease leaching and control erosion (Robinson et al., 2003). Indeed, roots can help prevent the formation of reduced PTE species, which have often been reported to be more toxic and more mobile than oxidized species. The roots can also add organic matter to the substrate that binds the PTE (Robinson et al., 2009). Two of these tree species (O. carpinifolia and $F$. ornus) have been proposed for the stabilization of a mining area after soil reconstruction in NW Greece (Zagas et al., 2010).

The second group of relevant tree species includes those that grew well and accumulated PTE. During the screening and analysis of data, our results indeed showed that of the 38 total studied trees species from the three sites, 4 genera exhibited a clear capacity to accumulate PTE in their aboveground biomass. Generally, the Betula, Populus, Quercus and Salix species accumulated significantly more PTE compared with the other tree species. The accumulation of $\mathrm{Zn}$ and $\mathrm{Cd}$ by members of the Salicaceous family is now well established (Ciadamidaro et al., 2014; Madejon et al., 2013; Robinson et al., 2006). In more detail, S. aquatica grandis, $P$. oxford and B. pubescens accumulated $\mathrm{Cd}, \mathrm{Pb}$, and $\mathrm{Zn}$ at the Carrièressous-Poissy and Leforest sites, whereas $\mathrm{Fe}, \mathrm{Mn}$ and $\mathrm{S}$ were accumulated by S. aquatica grandis, Q. rysophylla, and B. papyrifera at the Thann site. However, in some cases, the rate of PTE accumulation was significantly different between the studied sites. In our work, for 
example, $S$. aquatica grandis was able to accumulate the highest concentrations of $\mathrm{Cd}$ and $\mathrm{Zn}$ in all sites, reaching maximum values of $\approx 128 \mu \mathrm{g} / \mathrm{g} \mathrm{D} \mathrm{Wt}$ for Cd and $\approx 2800 \mu \mathrm{g} / \mathrm{g} \mathrm{D}$ Wt for $\mathrm{Zn}$ in leaves (Table S2). The $\mathrm{Cd}$ accumulation rate in leaves was somehow linked to the $\mathrm{CaCl}_{2}$ extractable $\mathrm{Cd}$ fraction. At the Leforest site, the leaf $\mathrm{Cd}$ and the $\mathrm{CaCl}_{2}$ extractable contents were 4- and 5-fold higher than those at the Carrières-sous-Poissy site, respectively. The lowest Cd content in $S$. aquatica grandis leaves $(<2.5 \mu \mathrm{g} / \mathrm{g} \mathrm{D} \mathrm{Wt})$ was recorded at the Thann site, where the $\mathrm{CaCl}_{2}$ extractable $\mathrm{Cd}$ fraction was lower than the detection limit. $\mathrm{Zn}$ concentrations, in leaf and soil samples were in the same order of magnitude at the two Carrières-sous-Poissy and Leforest sites. In this context, among the trees used in phytomanagement, the species able to tolerate and accumulate high concentrations of PTE (Ali, 2013) in their tissues without visible toxicity symptoms are considered hyperaccumulators. S. aquatica grandis may possibly be considered as a $\mathrm{Cd}$ and $\mathrm{Zn}$ hyperaccumulator in our study (Leforest site). It remains to be determined whether its growth will be affected in the long term by the high availability of $\mathrm{Cd}$ and $\mathrm{Zn}$ at the Leforest site.

At the Thann site, $Q$. rysophylla and B. papyrifera showed the best accumulation capacities for Mn but it seems that there was no relation between the $\mathrm{Mn}$ in leaf tissues and that in the $\mathrm{CaCl}_{2}$ extractible fraction. For the two Quercus petraea and Q. pedunculata species present at both the Leforest and Carrières-sous-Poissy sites, the leaf Mn levels were similar, whereas the Mn contents in the soil at the Leforest site were 6 times as high as those observed at Carrières-sous-Poissy. These results could support the hypothesis that Quercus genera presents accumulation capacities for Mn independently of soil physic-chemical characteristics and Mn concentrations in soil.

It is worth highlighting that the trees used for the phytoextraction of PTE from the soil must be efficient in accumulating PTE mostly in leaves and stems (Gomes et al., 2012; Rascio and Navari- Izzo, 2011). In the present study, although the highest PTE concentrations were 
393 found in leaves compared to stems, the correlation coefficient between PTE in leaves and 394 stems showed significant positive correlations for all elements, except for the $\mathrm{Pb}$ and $\mathrm{S}$ 395 concentrations in the Carrières-sous-Poissy site and for Fe in the Thann and Leforest sites 396 (Table 4). In general, the strongest correlations in all three sites were observed for $\mathrm{Zn}$ and $\mathrm{Cd}$, 397 especially considering that $\mathrm{Zn}$ and $\mathrm{Cd}$ seem to have similar geochemical and environmental 398 properties, and they can interact during plant uptake, transport and accumulation in leaves and 399 stems (Das et al., 1997, Han et al., 2010). In the case of Cd, Pulford and Watson (2003) 400 determined that the compartmentalization of PTE within trees is considered to vary greatly by species and clones. Yang et al. (2015) showed that in the aboveground tissues of willows, Cd 402 is usually sequestered in vacuoles, by which the toxic effects of $\mathrm{Cd}$ can be greatly minimized. 403 Moreover, Salt et al. (1995) and Vassilev et al. (2005) concluded that the distribution and 404 translocation of $\mathrm{Cd}$ to aboveground tissues were primarily driven by the transpiration stream. 405 In the case of Zn, previous studies (Maxted et al., 2007; Migeon et al., 2009) agreed with our results and found significantly more $\mathrm{Zn}$ in the leaves than in the stems of Salicaceous species. For Mn, significant correlations were obtained, especially at the Thann site, between 408 leaf and stem contents (Table 4). This could be related to the ability of Mn to be rapidly taken 409 up and translocated within plants (Kabata-Pendias and Pendias, 2001). It is worth noting that 410 Mn was efficiently taken up in the Betula and Quercus species, despite its very low $\mathrm{CaCl}_{2}$ 411 availability at the Thann site (Table 3). This may be due to either intrinsic capabilities or to a 412 specialized microbial community that may reduce the Mn mostly present in the soil as Mn 413 oxides (Zappelini et al., in preparation).

414 Concerning Pb, previous studies (Baker, 1981; Borisěv et al., 2009; Stoltz and Greger, 415 2002) observed restricted translocation from roots to stems and leaves due to a PTE exclusion 416 mechanism in roots by which plants avoid damages in their photosynthetic processes. 417 Moreover, $\mathrm{Pb}$ is considered to have low solubility and therefore a low availability to plants 
418 because it precipitates as phosphates and sulfates found in the rhizosphere of plants, as exemplified by Blaylock and Huang (2000). Indeed, we could not recover the $\mathrm{Pb}$ in the $\mathrm{CaCl}_{2}$ fraction, despite its elevated total concentration, especially at the Carrières-sous-Poissy site. Although many studies have evinced that mycorrhizal fungus association could enhance tree growth and vitality on TE-disturbed habitats and reduce PTE toxicity, affecting tree PTE uptake and accumulation in plant tissues (Ciccatelli et al., 2010; Liu et al., 2014), no significant effect of mycorrhizal inoculation on tree development or PTE accumulation in trees was observed in our experimental conditions. It is well known that the effect of AM fungi on plant parameters depends on many factors, including tree and fungus species, the growth conditions of the tree, tree age, soil properties, and the type and concentration of PTE in the soil (Arriagada et al., 2005; Mrnka et al., 2012). The lack of beneficial effect, in contrast to those obtained in our previous study (Ciadamidaro et al. 2017), is probably due to the fact that a single endomycorrhizal fungal species was used here and that some of the tested trees are not as perceptive as poplars to endomycorrhizal colonization in their early growth stage. Despite differences in the characteristics of the three soils and of their original contamination, the behavior in growth and PTE uptake of the different tree species was quite similar at all sites, indicating that the overall effect species is more important than the effect of the inoculation, as stated by the MANOVA analysis.

\section{Conclusions}

Among the 38 total studied species, 4 species (A. subcordata, P. orientalis, U. pumila, O. carpinifolia and the 3 studied Acer), only seldom used before in a phytomanagement strategy, showed the highest growth capacity. Moreover, these tree species that produced a clean biomass could be considered as good candidates for the phytomanagement of marginal lands, for their valuation in various industrial sectors. Indeed, while it is necessary to treat the by-product fractions enriched in PTE when using contaminated biomass (Chalot et al., 2012, 
443 Asad et al., 2017, Bert et al., 2017), using this non-accumulating biomass would allow

444 researchers to by-pass this additional step. In contrast, $S$. aquatica grandis, $P$. oxford, 445 Q. rysophylla and B. papyrifera trees were able to take up high quantities of one or more of 446 the analyzed PTE without presenting toxic symptoms. For this reason, they could be classified 447 as phytoextracting species and used with regard to the restoration objectives and a PTE 448 management strategy. Indeed, these species with TE-enriched biomass could lead to the 449 marketing of a truly eco-innovating production chain that could meet the needs of an 450 emerging, high-prospect market within the bio-economy, such as eco-catalysis (Grison, 451 2015). These innovative eco-solutions for the treatment of polluted soils respond perfectly to 452 the needs of sustainable development.

Moreover, the most promising tree species could be retained, and a model stabilizer and accumulator/hyperaccumulator tree could be used as a control to study fundamental processes. This will permit (i) the recovery of PTE-contaminated sites from belowground to aboveground biomass and (ii) the production of valuable materials and fuels, focusing on the catalysis of industrial chemicals, performance and high-tech products, e.g., pharmaceutical, cosmetics, and flavors. A future comparative analysis of catalytic systems derived from hyperaccumulating and accumulating trees will be useful for a better understanding of phytomanagement processes.

\section{Acknowledgements}

463 We acknowledge Dr. Caroline Amiot for the ICP-AES analyses. We thank Jean Michel Colin 464 (CRISTAL Co., France), Elsa Borujerdi (Grand Paris Seine \& Oise, France) and Guillaume 465 Lemoine (Etablissement Public Foncier Nord-Pas de Calais, France) for providing us access 466 to the Thann, Carrières-sous-Poissy and Leforest experimental sites, respectively. The authors declare no conflicts of interest. 


\section{Funding sources}

This work was supported by the French National Research Agency [PHYTOCHEM ANR-13CDII-0005-01], the French Environment and Energy Management Agency [PROLIPHYT ADEME-1172C0053], the Région Franche-Comté [Environnement-Homme-Territoire 2014069] and the Pays de Montbéliard Agglomération [13/070-203-2015].

\section{References}

Ali, H., Khan, E., Sajad, M.A., 2013. Phytoremediation of heavy metals-Concepts and applications. Chemosphere. 91: 869-881.

Arriagada, C., Herrera, M.A., Ocampo, J.A., 2005. Contribution of arbuscular mycorrhizal and saprobe fungi to the tolerance of Eucalyptus globulus to $\mathrm{Pb}$. Water Air and Soil Pollution. 166: $31-47$.

Asad, M., Menana, Z., Ziegler-Devin, I., Bert, V., Chalot, M., Herzig, R., Mench, M., Brosse, N., 2017. Pretreatment of trace element-enriched biomasses grown on phytomanaged soils for bioethanol production. Industrial Crops and Products. 107: 63-72.

Assad, M., Tatin-Froux, F., Blaudez, D., Chalot, M., Parelle, J., 2017. Accumulation of trace elements in edible crops and poplar grown on a titanium ore landfill. Environmental Science and Pollution Research. 24: 5019-5031.

Azimi, S., Ludwig, A., Thévenot, D.R., Colin, J.-L., 2003. Trace metal determination in total atmospheric deposition in rural and urban areas. Science of the Total Environment. 308: 247256.

Baker, A.J.M., 1981. Accumulators and excluders - strategies in the response of plants to heavy metals. Journal of Plant Nutrition. 3: 643-654. 
Bert, V., Allemon, J., Sajet, P., Dieu, S., Papin, A., Collet, S., Gaucher, R., Chalot, M., Michiels, B., Raventos, C., 2017. Torrefaction and pyrolysis of metal-enriched poplars from phytotechnologies: Effect of temperature and biomass chlorine content on metal distribution in end-products and valorization options. Biomass and Bioenergy. 96: 1-11.

Blaylock, M.J., Huang, J.W., 2000. Phytoextraction of metals. In: Raskin I, Ensley BD, editors. Phytoremediation of toxic metals: using plants to clean up the environment. Toronto: John Wiley and Sons, Inc. p. 303.

Borišev, M., Pajevic', S., Nikolic', N., Pilipovic', A., Krstic', B., Orlovic', S., 2009. Phytoextraction of $\mathrm{Cd}, \mathrm{Ni}$, and $\mathrm{Pb}$ using four willow clones (Salix spp.). Polish Journal of Environmental Studies. 18: 553-561.

Bowen, H.J.M., 1979. Environmental Chemistry of the Elements. Academic Press, London.

Chalot, M., Blaudez, D., Rogaume, Y., Provent, A.-S., Pascual, C., 2012. Fate of trace elements during the combustion of phytoremediation wood. Environmental Science and Technology. 46: 13361-13369.

Ciadamidaro, L., Madejòn, E., Robinson, B., Madejòn, P., 2014. Soil plant interactions of Populus alba in contrasting environments. Journal of Environmental Management. 132: 329337.

Ciadamidaro, L., Girardclos, O., Bert, V., Zappelini, C., Yung, L., Foulon, J., Papin, A., Roy, S., Blaudez, B., Chalot, M., 2017. Poplar biomass production at phytomanagement sites is significantly enhanced by mycorrhizal inoculation Environmental and Experimental Botany. 139: 48-56.

Ciccatelli, A., Lingua, G., Todeschini, V., Biondi, S., Torrigiani, P., Castiglione, S., 2010. 

516 Environmental Pollution. 98: 29-36.

517 Dickinson, N.M., 2006. Phytoremediation of industrially- contaminated sites using trees. 518 NATO Science Series. 68: 229-240.

Arbuscular mycorrhizal fungi restore normal growth in a white poplar clone grown on heavy metal-contaminated soil, and this is associated with upregulation of foliar metallothionein and polyamine biosynthetic gene expression. Annals of Botany. 106: 791-802.

Das, P., Samantaray, S., Rout, G.R., 1997. Studies on cadmium toxicity in plants: a review.

\author{
NATO Science Series. $68: 229-240$.
}

Domínguez, M.T., Marañón, T., Murillo, J.M., Schulin, R., Robinson, B.H., 2008. Trace element accumulation in woody plants of the Guadiamar Valley, SW Spain: A large-scale phytomanagement case study. Environmental Pollution. 152: 50-59.

Douay, F., Pruvot, C., Waterlot, C., Fritsch, C., Fourrier, H., Loriette, A., et al., 2009. Contamination of woody habitat soils around a former lead smelter in the North of France, Science of the Total Environment. 407: 5564-5577. Europe's
environment
The
fourth
assessment (http://www.eea.europa.eu/publications/state_of_environment_report_2007_1).

Evangeloua, M.W.H., Deramb, A., Gogosa, A., Studera, B., Schulin, R., 2012. Assessment of suitability of tree species for the production of biomass on trace element contaminated soils. Journal of Hazardous Materials. 209-210: 233-239.

French, Ch.J., Dickinson, N.M., Putwain, P.D., 2006. Woody biomass phytoremediation of contaminated brown- field land. Environmental Pollution. 141: 387-395.

Gomes, M.P., Marques, T.C.L.L.S.M., Carneiro, M.M.L.C., Soares, Â.M., 2012. Anatomical characteristics and nutrient uptake and distribution associated with the Cd-phytoremediation 
534 capacity of Eucalyptus camaldulenses Dehnh. Journal of Soil Science and Plant Nutrition. 12: $535 \quad 481-496$.

536 Grison, C., 2015. Combining phytoextraction and ecocatalysis: a novel concept for greener 537 chemistry, an opportunity for remediation. Environmental Science and Pollution Research. 538 22: 5589-5591.

539 Han, S., Kim, D., Lee, J., 2010. Cadmium and zinc interaction and phytoremediation potential 540 of seven Salix caprea clones, Journal of Ecological Environment. 33: 245-251.

541 Houba, V.J., Lexmond, Th.M,. Novozamsky, I., Van der Lee, J.J., 1996. The state of the art 542 and future developments in soil analysis for bioavailability assessment. Science of the Total 543 Environment. 178: 21-28.

544 Kirkham, M.B., 2006. Cadmium in plants on polluted soils: effects of soil factors, 545 hyperaccumulation, and amendments. Geoderma. 137: 19-32.

546 Lamy, I., van Oorti, F., Dere, C., Baize, D., 2006. Use of major- and trace-element 547 correlations to assess metal migration in sandy Luvisols irrigated with wastewater. European 548 Journal of Soil Science. 57: 751-740.

549 Leyval, C., Joner, E.J., del Val, C., Haselwandter, K., 2002. Potential of arbuscular 550 mycorrhizal fungi for bioremediation. In Mycorrhizal Technology in Agriculture. Edited by: 551 Gianinazzi S, Schuepp H, Barea JM, Haselwandter K. Switzerland: Birkhäuser Verlag, 175552186.

553 Liu, L., Gong, Z., Zhang, Y., Li, P., 2014. Growth, cadmium uptake and accumulation of 554 maize (Zea mays L.) under the effects of arbuscular mycorrhizal fungi. Ecotoxicology. 23: $555 \quad 1979-1986$. 
Kabata-Pendias, H. Pendias, Trace Elements in Soils and Plants, CRC Press, Boca Raton, FL, 2001.

558 Khan, S., Hesham, A.E.L., Qiao, M., Rehman, S., He, J.Z., 2010. Effects of Cd and Pb on soil 559 microbial community structure and activities. Environmental Science and Pollution Research. $560 \quad 17: 288-296$.

561 Madejón, P., Ciadamidaro, L., Marañón, T., Murillo, J.M., 2013. Long-Term Biomonitoring 562 of Soil Contamination Using Poplar Trees: Accumulation of Trace Elements in Leaves and 563 Fruits. International Journal of Phytoremediation. 15: 602-614.

564 Maxted, A.P., Black, C.R., West, H.M., Crout, N.M.J., McGrath, S.P., Young, S.D., 2007. 565 Phytoextraction of cadmium and zinc by Salix from soil historically amended with sewage 566 sludge. Plant and Soil. 290: 157-172.

567 Meers, E., Vandecasteele, B., Ruttens, A., Vangronsveld, J., Tack, F.M.G., 2007. Potential of 568 five willow species (Salix spp.) for phytoextraction of heavy metals. Environmental and 569 Experimental Botany. 60: 57-68.

570 Meier, S., Borie, F., Bolan, N., 2012. Phytoremediation of metal-polluted soils by arbuscular 571 mycorrhizal fungi. Critical Reviews in Environmental Science and Technology. 42: 741-775.

572 Mench, M., Schwitzguébel, J.P., Schroeder, P., Bert, V., Gawronski, S., Gupta, S., 2009. 573 Assessment of successful experiments and limitations of phytotechnologies: contaminant 574 uptake, detoxification and sequestration, and consequences for food safety. Environmental 575 Science and Pollution Research. 16: 876-900.

576 Mench, M., Lepp, N., Bert, V., Schwitzguébel, J.P., Gawronski, S.W., Schröder, P., 577 Vangronsveld, J., 2010. Successes and limitations of phytotechnologies at field scale: 
outcomes, assessment and outlook from COST Action 859. Journal of Soils and Sediments. 10: 1039-1070.

Mertens, J., Van Nevel, L., De Schrijver, A., Piesschaert, F., Oosterbaan, A., Tack, F.M.G., Verheyen, K., 2007. Tree species effect on the redistribution of soil metals. Environmental Pollution. 149: 173-181.

Migeon, A., Richaud, P., Guinet, F., Chalot, M., Blaudez, D., 2009. Metal accumulation by woody species on contaminated sites in the north of France. Water, Air and Soil Pollution. 204: 89-101.

Moreira, H., Pereira, S.I.A., Marques, A.P.G.C., Range, A.O.S.S., Castro, P.M.L., 2016. Mine land valorization through energy maize production enhanced by the application of plant growth-promoting rhizobacteria and arbuscular mycorrhizal fungi. Environmental Science and Pollution Research. 23: 6940-6950.

Mrnka, L., Kuchár, M., Cieslarová, Z., Matějka, P., Száková, J., Tlustoš, P., Vosátka, M., 2012. Effect of endo- and ectomycorrhizal fungi on physiological parameters and heavy metals accumulation of two species from the family Salicaceae. Water Air and Soil Pollution. 223: 399-410.

Pauget, B., Gimbert, F., Coeurdassier, M., Crini, N., Pérès, G., Faure, O., Douay, F., Richard, A., Grand, C., de Vaufleury, A., 2013. Assessing the in situ bioavailability of trace elements to snails using accumulation kinetics. Ecological Indicators. 34: 126-135.

Phanthavongsa, P., Chalot, M., Papin, A., Lacercat-Didier, L., Roy, S., Blaudez, D., Bert, V., 2017. Effect of mycorrhizal inoculation on metal accumulation by poplar leaves at phytomanaged sites. Environmental and Experimental Botany. 143: 72-81.

Pilon-Smits, E.A.H., 2005. Phytoremediation. Annual Revision of Plant Biology. 56: 15-39. 
601 Pourrut, B., Lopareva-Pohu, A., Pruvot, C., Garçon, G., Verdin, A., Waterlot, C., Bidar, G., 602 Shirali, P., Douay, F., 2011. Assessment of fly ash-aided phytostabilisation of highly 603 contaminated soils after an 8-year field trial. Part 2. Influence on plants. Science of the Total 604 Environment. 409: 4504-4510.

605 Pulford, I.D., Watson, C., 2003. Phytoremediation of heavy metal-contaminated land by trees 606 a review. Environmental Interantional. 29: 529-540.

607

Rascio, N., Navari-Izzo, F., 2011. Heavy metal hyperaccumulating plants: How and why do 608 they do it? And what makes them so interesting? Plant Science. 180: 169-181.

Robinson, B., Green, S., Mills, T., Clothier, B., van der Velde, M., Laplane, R., Fung, L.,

Deurer, M., Hurst, S., Thayalakumaran, T., van den Dijssel, C., 2003. Phytoremediation: using plants as biopumps to improve degraded environments. Australian Journal of Soil Research. 41: 599-611.

Robinson, B., Schulin, R., Nowack, B., Roulier, S., Menon, M., Clothier, B., Green, S., Mills, 614 T., 2006. Phytoremediation for the management of metal flux in contaminated sites. Forest 615 Snow and Landscape Research. 80: 221-234.

616 Robinson, B., Bañuelos, G., Conesa, H.M., Evangelou, M.W.H., Schulin, R., 2009. The 617 phytomanagement of trace elements in soil. Critical Reviews in Plant Science. 28: 240-266.

618 Salt, D.E., Prince, R.C., Pickering, I.J., Raskin, I., 1995. Mechanism of cadmium mobility and 619 accumulation in Indian mustard. Plant Physiology. 109: 1427-1433.

620 Sheoran, V., Sheoran, A.S., Poonia, P., 2010. Soil reclamation of abandoned mine land by 621 revegetation: a review. International Journal of Soil Sediment and Water. 3: 1-21. 
622 Sterckeman, T., Gomez, A., Ciesielski, H., 1996. Soil and waste analysis for environmental 623 risk assessment in France. Science of the Total Environment. 178: 63-69.

624 Stoltz, E., Greger, M., 2002. Accumulation properties of $\mathrm{As}, \mathrm{Cd}, \mathrm{Cu}, \mathrm{Pb}$ and $\mathrm{Zn}$ by four 625 wetland plant species growing on submerged mine tailings. Environmental and Experimental 626 Botany. 47: 271-280.

627 Vassilev, A., Perez-Sanz, A., Semane, B., Carleer, R., Vangronsveld, J., 2005. Cadmium 628 accumulation and tolerance of two Salix genotypes hydroponically grown in presence of 629 cadmium. Journal of Plant Nutrition. 28: 1-19.

630 Zagas, T., Tsitsoni, T., Ganatsas, P., Tsakaldimi, M., Skotidakis, T., Zagas, D., 2010. Land 631 Reclamation and Ecological Restoration in a Marine Area. International Journal of 632 Environmental Research. 4: 673-680.

633 Yang, J., Li, K., Zheng, W., Zhang, H., Cao, X., Lan, Y., Yang, C., Li, C., 2015. 634 Characterization of early transcriptional responses to cadmium in the root and leaf of Cd635 resitant Salix matsudana Koidz. BMC Genomics. 16: 705.

636 Yilmaz, D.D. and Perlak, K.U., 2011. Nickel-induced changes in lipid peroxidation, 637 antioxidative enzyme and metal accumulation in Lemna gibba. Internation Journal of 638 Phytoremediation. 13: 25-35. 